\title{
COUNSELLING ON THE ROLE OF WOMEN IN THE IMPLEMENTATION OF THE CONCEPT OF WASATHIYAH (MODERATE) ISLAM
}

\author{
Elis Teti Rusmiati and Rajab Ritonga \\ Universitas Prof. Dr. Moestopo (Beragama), Indonesia. \\ elistetirusmiati@dsn.moestopo.ac.id
}

\begin{abstract}
The idea of the concept of Wasathiyah Islam (moderate Islam) reappeared in the High Level Consultation (Summit) of World Muslim Scholars and Intellectuals at the Bogor Palace, 1-3 May 2018. Wasathiyah Islam is perceived as a perspective that understands the position of Islam between two extreme opposite points: Fundamentalist and radical on the one hand, and liberal and permissive on the other. Women are the party most defeated by Islamic fundamentalists and most disadvantaged in the application of rigid Islamic sharia in various places in the Islamic world. In connection with concept of Wasathiyah Islam, women have monitoring ability that can promote constructive dialogue and provide understanding, both in the family and in the community. Therefore, women need to be equipped with a full understanding of the concept of Wasathiyah Islam, because misleading understanding can foster religious radicalism on the one hand, and permissive attitudes will dwarf the understanding of religion on the other. The method used in this counselling includes several stages: 1) survey; 2) module making; 3) counselling; 4) interactive dialogue; 5) evaluation. The results of the counselling showed that after the training, participants enhanced their knowledge about the concept of Wasathiyah Islam. They began to realize that they had an important role in instilling a correct understanding of Wasathiyah Islam towards their families and communities.
\end{abstract}

Keywords: Wasathiyah Islam, Moderate, Role Of Women, Fundamentalist, Liberal.

\section{INTRODUCTION}

The term Wasathiyah is derived from Arabic which has three meanings: 1) Middle; in the middle position; 2) Fair. Someone who is fair in deciding things, meaning that he/she is not biased. She/he decided on a case with actual law; give the actual rights to the owner; 3) Wasathiyah also means the best thing, the choice or the noblest. These definitions are taken by several interpreters, one of which is taken from the Qur'an surah AlBaqarah verse 143:

"And thus we have made you a just community that you will be witnesses over the people and the Messenger will be a witness over you."

Wasathiyah Islam is agreed to be translated with moderate Islam at the Summit of World Muslim Scholars and Intellectuals at the Bogor Palace, May 1-3, 2018, which President Jokowi emphasized as a very important issue because it was related to tolerance, Ukhuwah Islamiyah (fellow Muslim brotherhood) and in tackling the spread of radicalism. The summit resulted in Bogor Message, as follows: (1) Recognizing the reality of recent modern civilization that shows chaos, uncertainty and the accumulation of global damage compounded by poverty, illiteracy, injustice, discrimination, and various forms of violence, both at national and global levels; (2) Believing Islam as a religion of peace and mercy (din al-salam wa al rahmah), the religion of justice (din adalah), and the religion of civilization (din alhadarah) whose basic teachings and principles teach love, compassion, harmony, unity, equality, peace and decency; (3) Recognizing that the paradigm of Wasathiyah Islam, as the main teachings of Islam, has been practiced in the course of history since the era of the Prophet Muhammad, the rightly guided caliph (al-Khilafah al-Rashida), to the modern and contemporary periods, in various countries throughout the world, as well as reaffirming the role and moral responsibility of Muslim scholars to ensure and preserve future generations to build the Ummatan Wasatan civilization; (4) In the Summit, the World Muslim Scholars and Intellectuals are committed to:

Strengthening the paradigm of Wasathiyah Islam which includes 7 (seven) main values, they are: a) Tawassut, position in the middle and straight road; b) I'tidal, behave proportionally and fairly with responsibility; 3) Tasamuh, recognize and respect differences in all aspects of life; Syura, prioritize consultations and resolve issues through deliberations to reach consensus; Islah, get involved in reformative and constructive actions for the common good; 6) Qudwah, pioneer noble initiatives and lead people for human welfare; 7) Muwatonah, recognize the Nation State and respects citizenship.Uphold the high values of the paradigm of Wasathiyah Islam as a culture of life individually and collectively, symbolizing the spirit and copies of the history of Islamic civilization. 
Strengthen the determination to prove to the world that Muslims are observing the paradigm of Wasathiyah Islam in all aspects of life.

Encourage Muslim countries and communities to take the initiative to spread the paradigm of Wasathiyah Islam, through the World Forum of Wasathiyah Islam, in order to establish the Ummatan Wasatan, a society that is just, peaceful, inclusive, harmonious, based on Islamic teachings and morality.

Moderate attitudes (wasathiyah) are also assumed to describe attitudes that are able to integrate two different dimensions: theocentric dimension (hablun min Allah) and anthropocentris (hablun min an-nas). These attitudes are not just the demands of the times but also the demands of the Qur'an. The meaning of wasathiyah must be settled properly, it cannot be taken from the understanding of extremists who tend to put forward a harsh attitude without compromise, or the understanding of liberalist groups who often interpret religious teachings very loosely.

Women have more time to interact both with family members and with the community, compared to men (husbands) who have business of working in the office. Domestic responsibilities played by women provide more opportunities in the monitoring process and in promoting constructive dialogue and in providing understanding, both in the family and in the community. This potential is the main asset for the effectiveness of their role in promoting the values contained in the concept of Wasathiyah Islam.

Understanding the true meaning of wasathiyah will be able to form a conscious attitude in moderate Islam in the real sense (ummatan wasathan), to realize world peace, without violence in the name of groups, races, ideologies and even religions. For these interests, it is necessary to instill a correct understanding to the community, especially women, so as not to get caught up in radicalism, fundamentalism and extremism in religion.

\section{IMPLEMENTATION METHOD}

The implementation of this community service uses counselling method. The writer chose the form of counselling as it adapts to material conditions that are informative. However, for the material enrichment, participants were given time to engage in active dialogue within a specified time.

Table 1. Stages of Community Service Activities

\begin{tabular}{|c|c|c|c|c|}
\hline \multirow{2}{*}{ No } & \multirow{2}{*}{ Activity Plan } & \multicolumn{3}{|c|}{ Involvement in activities } \\
\hline & & Lecturers & Students & Community \\
\hline 1 & $\begin{array}{l}\text { Survey and mapping of } \\
\text { participants' background } \\
\text { knowledge }\end{array}$ & $\begin{array}{l}\text { Formulate } \\
\text { instruments to } \\
\text { measure } \\
\text { participants' } \\
\text { knowledge }\end{array}$ & $\begin{array}{l}\text { Help conduct the } \\
\text { survey }\end{array}$ & $\begin{array}{l}\text { Provide time and } \\
\text { place for the } \\
\text { survey }\end{array}$ \\
\hline 2 & Module making & $\begin{array}{l}\text { Create module } \\
\text { content for the } \\
\text { counselling based } \\
\text { on the survey results }\end{array}$ & $\begin{array}{l}\text { Assist the process } \\
\text { of module } \\
\text { layouting }\end{array}$ & $\begin{array}{l}\text { Verify the } \\
\text { module in terms } \\
\text { of grammar }\end{array}$ \\
\hline 3 & $\begin{array}{l}\text { Counselling } \\
\text { 1) Introduction to the } \\
\text { concept of } \\
\text { Wasathiyah Islam }\end{array}$ & Provide material & $\begin{array}{l}\text { Accompany the } \\
\text { participants }\end{array}$ & $\begin{array}{l}\text { Take part in the } \\
\text { counselling } \\
\text { process }\end{array}$ \\
\hline & $\begin{array}{l}\text { 2) Implementation of } \\
\text { the concept of } \\
\text { Wasathiyah Islam } \\
\text { in the religious life } \\
\text { of families and } \\
\text { communities }\end{array}$ & & & \\
\hline & $\begin{array}{l}\text { 3) The role of women } \\
\text { in the } \\
\text { implementation of } \\
\text { the concept of } \\
\text { Wasathiyah Islam in } \\
\text { the religious life of } \\
\text { families and } \\
\text { communities }\end{array}$ & & & \\
\hline
\end{tabular}




\begin{tabular}{cllll}
\hline 4 & Interactive dialogue & $\begin{array}{l}\text { Listen, explain and } \\
\text { give solutions }\end{array}$ & $\begin{array}{l}\text { Accompany the } \\
\text { participants }\end{array}$ & $\begin{array}{l}\text { Take part in the } \\
\text { dialogue process }\end{array}$ \\
\hline 5 & Evaluation & $\begin{array}{l}\text { Assist in filling out } \\
\text { the evaluation sheet }\end{array}$ & $\begin{array}{l}\text { Disseminate and } \\
\text { collect } \\
\text { evaluation sheet } \\
\text { the }\end{array}$ & $\begin{array}{c}\text { Fill out the } \\
\text { evaluation sheet }\end{array}$ \\
\hline
\end{tabular}

Table 1. Indicators of Successful Activity

\begin{tabular}{llll}
\hline No & Indicator & Pre-activity & Post-activity achievement \\
\hline 1 & $\begin{array}{l}\text { Know the meaning of } \\
\text { Wasathiyah Islam } \\
\text { (moderate) }\end{array}$ & $\begin{array}{l}90 \% \text { of participants did not } \\
\text { know }\end{array}$ & $80 \%$ knew \\
\hline 2 & $\begin{array}{l}\text { Understand the basic } \\
\text { concept of Wasathiyah } \\
\text { Islam }\end{array}$ & $\begin{array}{l}\text { Have little understanding on } \\
\text { the basic concept of } \\
\text { Wasathiyah Islam }\end{array}$ & Have more understanding \\
\hline 3 & $\begin{array}{l}\text { Understand the role of } \\
\text { women in the } \\
\text { implementation of the } \\
\text { concept of Wasathiyah } \\
\text { Islam in the religious life } \\
\text { of families and } \\
\text { communities }\end{array}$ & $\begin{array}{l}\text { Have little understanding on } \\
\text { the role of women in the } \\
\text { implementation of the basic } \\
\text { concept of Wasathiyah Islam }\end{array}$ & Have more understanding \\
\hline
\end{tabular}

\section{RESULTS AND DISCUSSION}

This Community Service Activity was carried out in RW 05 Kelurahan Kutabaru Kecamatan Pasar Kemis, Regency of Tangerang, on Saturday, 20 October 2018. Participants of this activity consisted of Women Family Welfare Education Cadres (PKK) from 9 RTs in RW 05 Kutabaru. As usual, in the structural environment of the community, there are a group of women who are selected/assigned as PKK cadres both at RW and RT levels. Of the 50 people invited, there were 42 PKK cadres who could attend as the counseling participants. Both the survey stage and the counseling and its evaluation were carried out in the same place, namely in the Citizen's Hall of RW 05 Kutabaru.

Survey, as the first stage in this Community Service activity, was carried out when the cadre mothers had just finished serving at the Integrated Service Post (Posyandu) which was routinely held every month. The survey was carried out by distributing questionnaires containing open-ended questions related to their knowledge of Wasathiyah (moderate) Islam.

From the questionnaire distributed, it was found that most of the mothers did not know about the concept of Wasathiyah (moderate) Islam. Only few have heard the term moderate Islam. Most of the mothers have never heard of the term let alone related to its application in daily life. The results of this questionnaire were also strengthened by the results of direct interviews which showed similar conclusions.

Based on the survey results, there are some important materials that must be delivered related to the concept of Wasathiyah Islam in the Community Service activity: (1) Understanding of Wasathiyah Islam (Moderate Islam) in the view of interpreters and Bogor Massage as well as in the view of Western values, (b) The values contained in the concept of Wasathiyah Islam as contained in the Bogor Message; (3) The importance of understanding the concept of Wasathiyah Islam properly; (4) The role of women in the implementation of the concept of Wasathiyah Islam in daily activities both within the family and community.

The activity began with a speech from Deputy Chairman of RW, Mr. Muhamad Eddy, continued by the delivery of counseling material. Choice of words/sentences used in the delivery of material used simple words/sentences, used language that was easily understood by mothers and avoided mentioning terms in foreign languages. This was done to eliminate the "gap" between the writer as an academician and mothers as ordinary members of the community. These methods need to be done to create an interactive/dialogical atmosphere so that the counseling material is acceptable by the participants. 
Further, in an atmosphere that was created not too formal, interactive dialogue ensued and flowed without pause. Participants openly conveyed issues related to Wasathiyah Islam and several examples of movements that were deemed "deviant" from the actual concept.

Participants seemed enthusiastic in participating in each of the stages, especially when interactive dialogue took place, when they raised various questions. Participants could digest and understand the counseling material, and it could also be seen from the substance of the questions they asked. During the stages of this Community Service, 3 students also accompanied the participants so that the activity could run effectively and efficiently.

The final result of this activity is that participants know and understand the concept of Wasathiyah Islam and realize the importance of understanding it correctly. In addition, what is more important is that participants understand their role in applying the concept of Wasathiyah Islam in daily activities, both within the family and in the community. This Community Service activity was closed with a prayer and lunch together.

\section{CONCLUSION}

Some notes as a conclusion from the Counseling on the Role of Women in the Implementation of the Concept of Wasathiyah (Moderate) Islam are: (1) The results of the survey to PKK cadres as participants showed that majority $(80 \%)$ did not know and understand the concept of Wasathiyah Islam. Therefore, they did not know their role in the concept of Wasathiyah Islam; (2) The counseling process went well, and the participants were enthusiastic in taking part of the counseling; (3) The results of the evaluation after counselling showed that participants' knowledge on the Role of Women in the Concept of Wasathiyah Islam enhanced significantly. This shows that the counselling ran effectively.

\section{REFERENCES}

Adimihardja, Kusnaka and Hikmat, Harry. 2004. Participatory Research Appraisal dalam Pelaksanaan Pengabdian kepada Masyarakat. Humaniora Utama Press. Bandung.

Din: Dari Bogor Kita Gelindingkan Islam Wasathiyah ke Dunia https://www.republika.co.id/berita/nasional/politik/18/05/04/p87ngy330-din-dari-bogor-kitagelindingkan-islam-wasathiyah-ke-dunia

Hanapi, Mohd Shukri. The Wasatiyyah (Moderation) Concept in Islamic Epistemology: A Case Study of its Implementation in Malaysia, International Journal of Humanities and Social Science Vol. 4, No. 9(1); July 2014

Pesan dari Bogor untuk Dunia, ulama dan cendekiawan dunia ingin memperkuat kembali paradigma Islam wasathiyah https://www.republika.co.id/berita/dunia-islam/islam-nusantara/18/05/03/p8590s313-pesandari-bogor-untuk-dunia

Rabasa, Angel et.all. Building Moderate Muslim Networks, dalam Rand Corporation, Center For Middle East Public Policy https://www.rand.org/content/dam/rand/pubs/monographs/2007/RAND_MG574.pdf 